
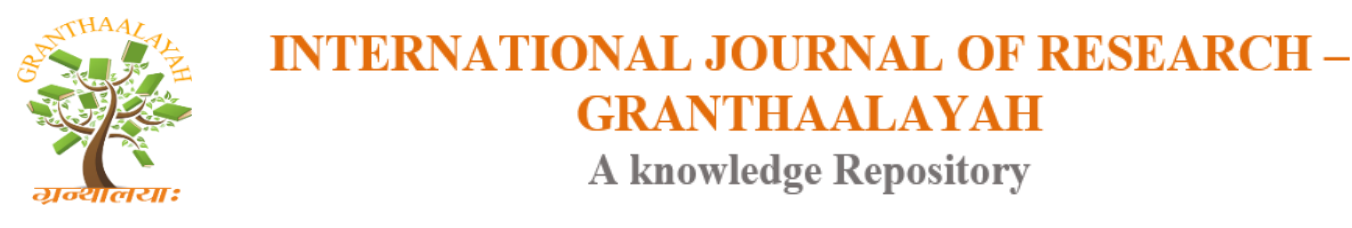

Management

\title{
FINANCIAL INCLUSION AND AGRICULTURAL DEVELOPMENT IN INDIA
}

\author{
Semanti Choudhury ${ }^{* 1}$ \\ ${ }^{* 1}$ Department of Economics, Jadavpur University, India
}

\begin{abstract}
In most parts of the world, especially in the developing nations, the poor face challenges that impair their conditions and limit their opportunities. In order for growth to be inclusive, it should benefit all sectors of the economy while reducing the disadvantages faced by the poor and the underprivileged, as well as ensuring equitable opportunities for all economic participants. In the context of a developing country like India where a major portion of the population is dependent on agriculture for their livelihood, agricultural development forms an important part of any growth measure. One of the many alternative strategies for attaining inclusive growth is through developing an inclusive financial system. Financial inclusion is instrumental to facilitate economic transaction, manage day-to-day resources, protect against vulnerability, improve quality of life, make productivity-enhancing investments and leverage assets. However, in the Indian agricultural scenario, financial inclusion is faced by various impediments. This paper analyses the significance of financial inclusion and social sector expenditure in the rural economy in promoting agricultural development and inclusive growth in India, and infers with the help of a proposition made in a constructed general equilibrium model. It also offers certain policy prescriptions in this domain.
\end{abstract}

Keywords: Agricultural Development; Financial Inclusion; Formal and Informal Credit; General Equilibrium; Inclusive Growth.

Cite This Article: Semanti Choudhury. (2018). "FINANCIAL INCLUSION AND AGRICULTURAL DEVELOPMENT IN INDIA." International Journal of Research Granthaalayah, 6(9), 421-433. https://doi.org/10.5281/zenodo.1451894.

\section{Introduction}

Developing countries in general have agriculture as their primary sector. In the developing economy of India too, agriculture is the source of livelihood for almost 58.4\% of the population. Though India is on a contemporary growth path with focus on manufacturing and service sector, it should be noted that it is also characterised by a heavy sum of unskilled labourers. Agriculture being a sector where these unskilled labourers can be employed to a great extent, growth of the agricultural sector is imperative. A large part of India's exports also comprises of primary and commercial agricultural commodities. Though the expansion of manufacturing and service sector may seem like a faster and easier process of growth and subsequent development, however, given 
the huge endowment of natural fertile land and geographical diversity, agriculture cannot be ignored in case of a developing country like India as the growth of the agricultural sector has the potential to effectuate overall economic development.

\subsection{Brief History}

Since independence India has made much progress in agriculture. Indian agriculture, which grew at the rate of about $1 \%$ per annum during the fifty years before Independence, has grown at a rate of about $2.6 \%$ per annum in the post-Independence era. Over the years, agriculture in India has experienced various kinds of reforms. The central theme of the First Five Year plan (1951-1956) was the development of the primary sector and agriculture. During this time and even in the early sixties, expansion of agricultural land was the source of growth. During 1966-67, a new strategy was undertaken to increase productivity in the agricultural sector by increasing the yield per hectare. This is popularly known as the Green Revolution. Broadly, post-independence agricultural policy can be distinguished into four phases:

The first phase is from 1947 to the mid-sixties. In this phase institutional changes and major irrigation projects were undertaken along with land reforms. The second phase considered the period from mid-sixties to 1980 and focused on increased productivity. The third phase included the period from 1980 to 1991. This phase witnessed the process of diversification which resulted in fast growth in non-foodgrain outputs like milk, fishery, poultry, vegetables, fruits etc. From 1991-92 onwards, we have the fourth phase. This phase was characterised by the 1991 reforms. With privatisation, liberalization and globalization paving their way into the Indian economy, agricultural exports received a boost. However, in the beginning of the $21^{\text {st }}$ century, the growth rate of agriculture was much lower than the country's overall growth rate. In the year 2000 the government adopted the New Agricultural Policy that aimed at achieving an output growth rate of $4 \%$ per annum in a sustainable manner with equity. However, the policy had failed to mention the subsequent steps of achieving the desired outcome.

\subsection{Inclusive Growth in India}

The Indian Government in regard to policymaking has taken up the concept of inclusive growth as the central theme of the $12^{\text {th }}$ five-year plan which emphasises on "Faster, More Inclusive and Sustainable Growth". Inclusive growth may be defined as "a concept that advances equitable opportunities for economic participants during economic growth with benefits incurred by every section of the society". Growth in the Indian economy can be made more inclusive by developing the vast agricultural sector of the country which forms the backbone of the country's economy. The aspects of inclusive growth include two broad interrelated categories, namely, financial inclusion and social sector spending. The former involves poverty alleviation and employment challenge through improved credit availability and allocation system. The latter is directed at better education, health and physical and social environment. Financial inclusion and social sector spending in the rural economy can generate equitable participation in the growth process thereby also ensuring percolation of the benefits of growth to the lower and deprived sections of the society. 
The different components of inclusive growth may be stated as follows:

- Poverty Reduction- This is possible through rapid growth of the priority sector that helps increase the incomes of a large number of people as also their capabilities and opportunities.

- Employment Generation- An inclusive growth programme is deemed successful if it succeeds in generating a higher level of employment with increased per capita income.

- Access to essential services- A person is referred to as poor not only when his/her endowment of wealth and property is meagre but also when his/her access to public facilities and natural resources is limited. Policies targeted at inclusive growth should provide equitable access to services and opportunities.

- Social justice and empowerment- All the participants of the economic society should have equal opportunity, mobility, dignity and freedom. Programs on inclusive growth should address the obstacles faced by the less privileged sections of the society.

- Environmental sustainability- For growth to be inclusive, it must be sustainable such that the effect is not a momentary one but one which is meaningful in the long run.

- Gender equity- One objective of inclusive growth policy should be to eliminate the social barriers faced by women at different stages of economic participation.

- Governance- The role of the state in the context of inclusive growth is important in the sense that the government should ensure rapid economic growth complemented by an increase in social welfare.

\subsection{Financial Inclusion and Social Sector Expenditure}

In India, with the approach of Twelfth Five Year plan (2012-2017), the issue of financial inclusion is emerging as the new paradigm of economic development. The term 'Financial Inclusion' refers to the 'transfer of banking services at a reasonable cost to the vast section of the deprived and low income group people' and is a development policy priority in many countries. The services that normally come under the purview of financial inclusion are credit supply, savings facility, insurance, payments and most remittance facilities. According to Amartya Sen (2000), poverty does not only indicate insufficient income, but also the deprivation of various capabilities including security and ability to participate in economic as well as political systems. Financial inclusion strives to connect the masses to banks and non-bank financial institutions and, in turn, accentuate the growth of a country and India is no exception in this respect.

There are two types of agricultural credit available in a developing country like India: formal credit and informal credit. Formal credit is that type of credit which is given out by banks and cooperatives and which has formal acknowledgement by registered authorities. Informal credit refers to the credit supplied by professional moneylenders, property owners, etc. usually to rural poor people who do not have enough mortgage-able assets to obtain formal credit from nationalised banks and other authorised financial institutions. Almost $40 \%$ of the population of India lacks access to basic financial facilities. Out of 19.9 crore households in India, only 6.82 crore households have access to banking services. As far as rural areas are concerned, out of 13.83 crore rural households in India, only 4.16 crore rural households have access to basic banking services. The Government of India has taken various initiatives to financially include the excluded section of the society (which have been discussed later in this paper). However, the rural credit market still remains under-penetrated. Of the approximately 68300 branches of Indian commercial 
banks, roughly 32400 (48\%) are in rural areas, as of 2005. But in terms of business, the rural branches have mobilised only $14 \%$ of the deposits. The issue at hand is formalisation of the informal financial sector in the rural areas of India.

\subsection{Summary}

In the following sections we shall explore the topic of financial inclusion for agricultural development and inclusive growth in the emerging economy of India. In section 2, we undertake a review of the current literature available on this topic. Section 3 provides an exploratory analysis based on available data. In section 4, we construct a three-sector general equilibrium model and perform the relevant comparative static exercise. Some policy recommendations in this context are provided in section 5. Section 6 concludes the paper.

\section{Literature Review}

This section undertakes a review of the existing literature on inclusive growth and financial inclusion as its component, the interaction of formal and informal credit markets in agriculture and the general equilibrium model used in this paper.

Raquel and Rafael (2013) have provided a debate on two operational definitions of inclusive growth combined with attempts to measure inclusive growth. One emphasises on a connection between the magnitude of variation in growth and inclusion, whereas, the other uses the covariation between growth in income and consumption as a proxy for inclusion. Both definitions and corresponding measures help assessing which set of policies are effective in achieving inclusive growth. According to Conroy (2005), financial exclusion is a process that prevents poor and disadvantaged social groups from acquiring access to the formal financial systems of their countries.

Chaudhuri (2001) studied the interaction of formal and informal credit markets in backward agriculture using mathematical tools by establishing Nash equilibrium. The paper assesses two alternative ways of formulating a credit subsidy policy, the first being the effects of an increase in the volume of formal credit supplied to the borrowers. It shows that if a credit subsidy policy is undertaken via this path, it is able to lower the interest rate on informal credit and improve both agricultural productivity and welfare of farmers. The second way is through a decrease in the rate of interest charged on formal credit. Our paper differs in the sense that it analyses the effects of increase in supply of formal credit in a three-sector general equilibrium framework. There exists limited work in the general equilibrium framework which addresses the impact of policy reforms in a set up where formal credit plays an active role in both urban manufacturing and rural export oriented agricultural sectors.

Das, Senapati, John (2009) studied the impact of agricultural credit on agricultural production using econometric tools. The analysis suggests that the direct agricultural credit amount has a positive and statistically significant impact on the output and its effect is immediate.

Gupta and Chaudhuri (1997) suggest that formal and informal credit may be complements or substitutes. According to Gupta and Chaudhuri (1997) the market for informal credit comes into 
existence because the needs of the farmers are not satisfied by formal credit since there is a delay in disbursement of formal credit. Our model also differs in its assumption of mobility of informal and formal capital between sectors. Also, in our model, we consider these two forms of credit to be perfectly substitutable in nature. Gupta and Chaudhuri (1997) suggest that the supply of formal credit is exogenously given, as is also assumed in our model, and the corresponding rate of interest is administratively fixed. The assumption of higher rate of interest on informal credit has also been established in the paper.

\section{Exploratory Data Analysis}

Though our country's economy is growing at a rate of around 9 percent, the growth is not inclusive. High growth of the Indian economy is combined with high level of inequality with the richest 6\% of the population earning approximately $25 \%$ of the country's total income. Agricultural backwardness is one of the prime reasons behind the prevalence of such inequality and poverty. In this section, we analyse agricultural growth and rural flow of credit in the post-reforms period with the help of available data.

\subsection{Analysis of Gross Domestic Product}

We consider the following table for the analysis of the gross domestic product (GDP) of agriculture and allied sectors with respect to the total GDP of the country:

Table 1: Growth Rates of Total Gdp And Agricultural Gdp

\begin{tabular}{|l|l|l|l|l|l|}
\hline $\begin{array}{c}\text { Financial } \\
\text { Year }\end{array}$ & $\begin{array}{c}\text { Total Gdp } \\
\text { (In Rs. } \\
\text { Crores) }\end{array}$ & $\begin{array}{c}\text { Agricultural } \\
\text { Gdp (In Rs. } \\
\text { Crores) }\end{array}$ & $\begin{array}{c}\text { \% Share of } \\
\text { Agriculture in } \\
\text { Total Gdp }\end{array}$ & $\begin{array}{c}\text { Growth } \\
\text { Rate of } \\
\text { Total Gdp }\end{array}$ & $\begin{array}{c}\text { Growth Rate } \\
\text { of Agricultural } \\
\text { Gdp }\end{array}$ \\
\hline $1990-1991$ & $13,47,889$ & $3,36,164$ & 24.94 & - & - \\
\hline $1991-1992$ & $13,67,171$ & $3,28,394$ & 24.02 & 1.43 & -2.31 \\
\hline $1992-1993$ & $14,40,504$ & $3,51,627$ & 24.41 & 5.36 & 7.07 \\
\hline $1993-1994$ & $15,22,344$ & $3,62,775$ & 23.83 & 5.68 & 3.17 \\
\hline $1994-1995$ & $16,19,694$ & $3,79,980$ & 23.46 & 6.39 & 4.74 \\
\hline $1995-1996$ & $17,37,741$ & $3,76,221$ & 21.65 & 7.29 & -0.98 \\
\hline $1996-1997$ & $18,76,319$ & $4,15,417$ & 22.14 & 7.97 & 10.40 \\
\hline $1997-1998$ & $19,57,032$ & $4,02,953$ & 20.59 & 4.30 & -2.97 \\
\hline $1998-1999$ & $20,87,828$ & $4,31,763$ & 20.68 & 6.68 & 7.12 \\
\hline $1999-2000$ & $22,54,942$ & $4,42,194$ & 19.61 & 8.00 & 2.41 \\
\hline $2000-2001$ & $23,48,481$ & $4,39,401$ & 18.71 & 4.15 & -0.61 \\
\hline $2001-2002$ & $24,74,962$ & $4,67,768$ & 18.90 & 5.39 & 6.46 \\
\hline $2002-2003$ & $25,70,935$ & $4,29,860$ & 16.72 & 3.88 & -8.14 \\
\hline $2003-2004$ & $27,75,749$ & $4,76,319$ & 17.16 & 7.97 & 10.84 \\
\hline $2004-2005$ & $29,71,464$ & $4,76,623$ & 16.04 & 7.05 & 0.07 \\
\hline $2005-2006$ & $32,53,073$ & $5,02,925$ & 15.46 & 9.48 & 5.53 \\
\hline $2006-2007$ & $35,64,364$ & $5,23,605$ & 14.69 & 9.57 & 4.13 \\
\hline $2007-2008$ & $38,96,636$ & $5,56,829$ & 14.29 & 9.32 & 6.34 \\
\hline
\end{tabular}




\begin{tabular}{|l|l|l|l|l|l|}
\hline $2008-2009$ & $41,58,676$ & $5,55,599$ & 13.36 & 6.72 & -0.27 \\
\hline $2009-2010$ & $45,16,071$ & $5,57,735$ & 12.35 & 8.59 & 0.41 \\
\hline $2010-2011$ & $49,18,533$ & $6,10,882$ & 12.42 & 8.91 & 9.54 \\
\hline $2011-2012$ & $52,47,530$ & $6,43,347$ & 12.26 & 6.69 & 5.34 \\
\hline
\end{tabular}

Source: Central Statistical Organisation (CSO)

In the post-reforms period in India, total GDP has experienced a high growth rate, reaching the maximum of $9.57 \%$ in 2006-2007. However, the growth rate of agricultural GDP has been lagging. The following graphical comparison clearly shows the disparity in growth rates of total GDP and agricultural GDP:

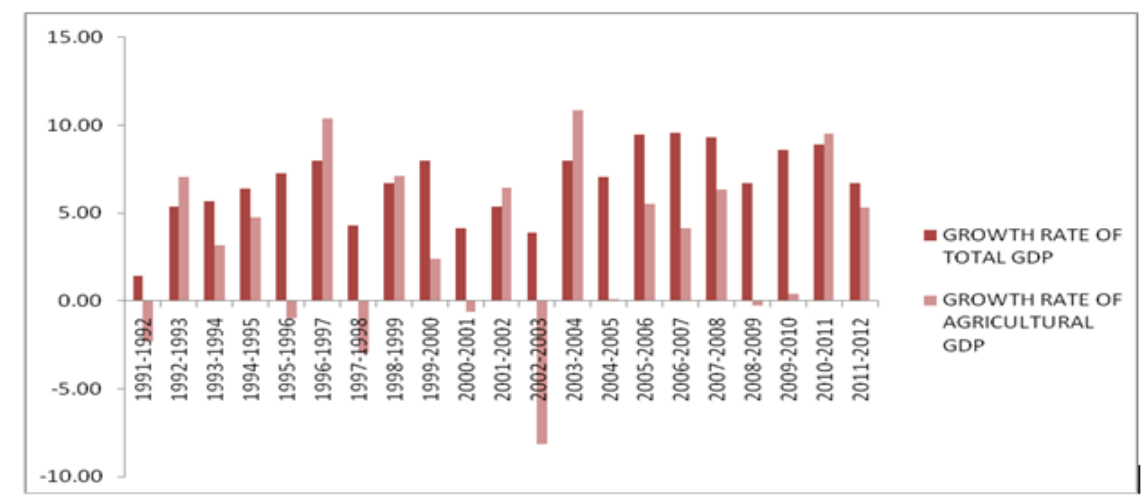

(Constructed on basis of TABLE 1)

Figure 1:

We see that the growth rate of agricultural GDP has mostly been less than that of the county's total GDP, even attaining negative values in the years 1991-92, 1995-96, 1997-98, 2000-01, 2002-03 and 2008-2009. It is evident that growth in India does not imply simultaneous development of all sectors.

In a labour surplus country like India, where a major portion of the labour force is dependent on agriculture, the contribution of agriculture to the total GDP of the country shows a declining route, thus indicating the existence of disguised unemployment and poverty. This is seen in the following graph:

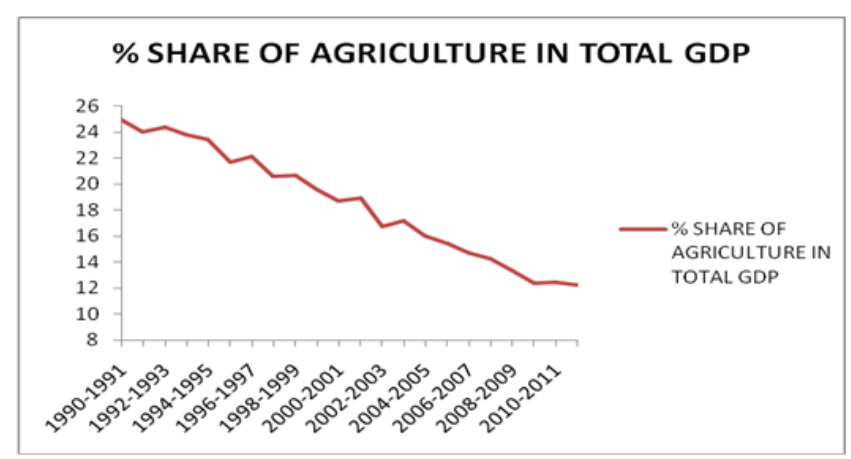

Figure 2:

(Constructed on basis of TABLE 1) 


\subsection{Distribution of Banks in Rural India}

The composition of the rural economy in India with respect to distribution of different types of banks has been shown in the following exploratory analysis:

Table 2: Bank Group-Wise Number of Branches in Rural Region

\begin{tabular}{|l|l|}
\hline Bank Group & Number of Branches \\
\hline Public Sector Banks & 23286 \\
\hline Private Sector Banks & 1937 \\
\hline Foreign Banks & 8 \\
\hline Regional Rural Banks & 12722 \\
\hline Total & $\mathbf{3 7 9 5 3}$ \\
\hline
\end{tabular}

Source: Reserve Bank of India Reports

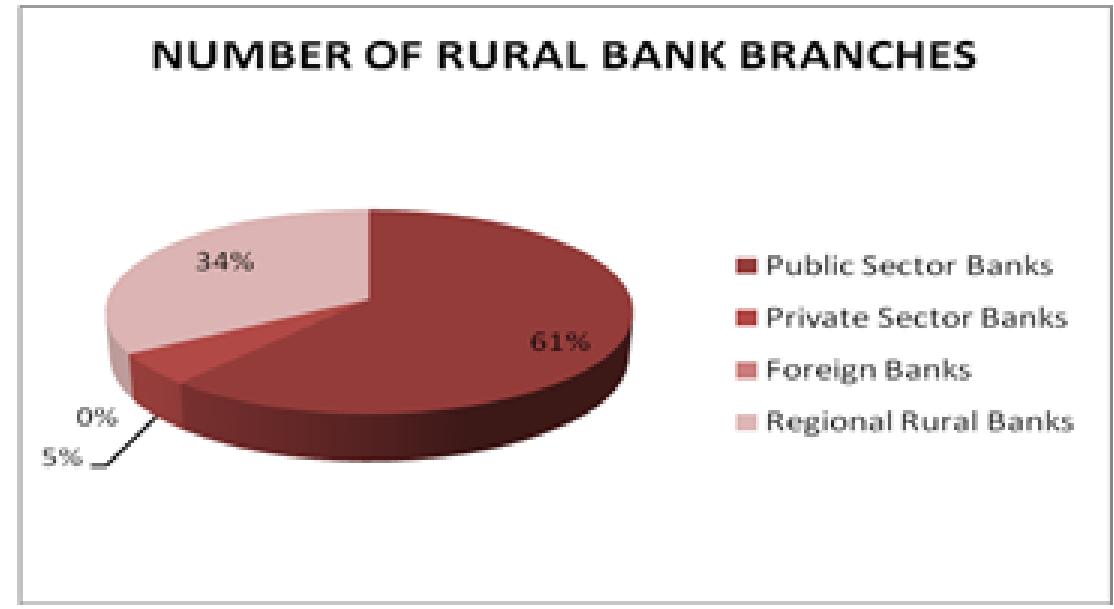

(Constructed on basis of TABLE 2)

Figure 3:

\subsection{Credit Flow in Agriculture}

By credit flow in agriculture, we indicate the flow of formal agricultural credit. The following table shows the increase in credit flow over the years, together with agricultural production:

Table 3: Credit Flow in Agriculture

\begin{tabular}{|l|l|l|}
\hline Year & $\begin{array}{l}\text { Total Credit Flow to Agriculture (In Rs. } \\
\text { Billion) }\end{array}$ & $\begin{array}{l}\text { Agricultural Production (In Rs. } \\
\text { Billion) }\end{array}$ \\
\hline $1991-92$ & 143.321 & 3902.01 \\
\hline $1992-93$ & 152.392 & 4161.53 \\
\hline $1993-94$ & 261.137 & 4299.81 \\
\hline $1994-95$ & 326.603 & 4502.58 \\
\hline $1995-96$ & 429.285 & 4471.27 \\
\hline $1996-97$ & 473.306 & 4914.84 \\
\hline $1997-98$ & 516.319 & 4789.33 \\
\hline $1998-99$ & 577.225 & 5092.03 \\
\hline
\end{tabular}




\begin{tabular}{|l|l|l|}
\hline $1999-00$ & 1342.089 & 5227.95 \\
\hline $2000-01$ & 1476.005 & 5227.55 \\
\hline $2001-02$ & 1509.988 & 5541.57 \\
\hline $2002-03$ & 1701.939 & 5175.59 \\
\hline $2003-04$ & 1919.457 & 5643.91 \\
\hline $2004-05$ & 2486.039 & 5654.27 \\
\hline $2005-06$ & 3013.287 & 5944.87 \\
\hline $2006-07$ & 3747.52 & 6191.9 \\
\hline $2007-08$ & 3939.62 & 6550.8 \\
\hline
\end{tabular}

Source: Handbook on Statistics on Indian Economy, RBI annual publications website, Central Statistical Organisation (CSO)

In order to find some relation between credit flow to agriculture over the years and agricultural production in the corresponding years, we construct the following scatter diagram:

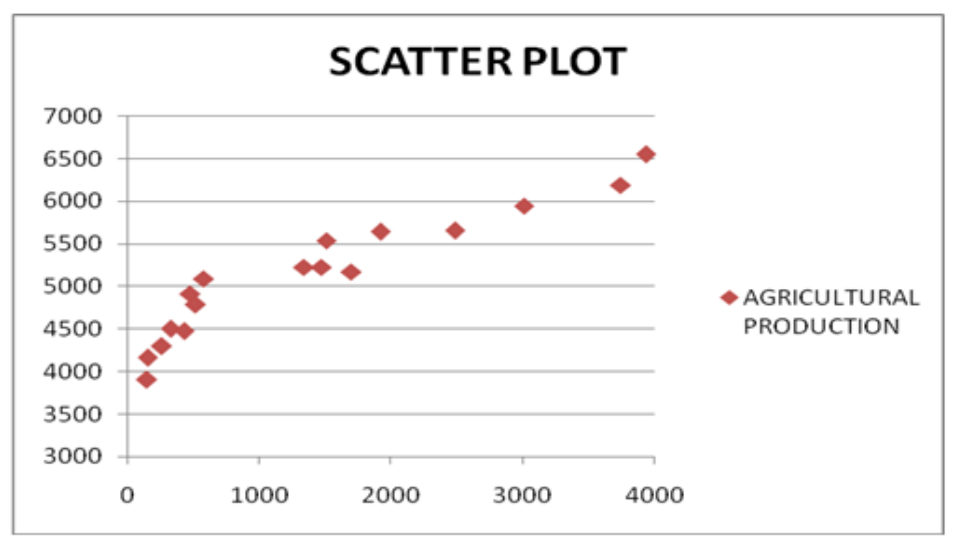

(Constructed on basis of TABLE 3)

Figure 4:

The scatter plot suggests that as credit flow to agriculture has increased over the years, agricultural production has also shown an increasing trend. Hence, from available data it can be interpreted that financial inclusion in agriculture has led to agricultural development.

\subsection{Correlation Analysis}

Till now, we have graphically analysed the nature of growth in agricultural production in connection with total GDP of the country and rural credit supply. We have already seen a positive relationship between credit flow and agricultural production. Now we want to see the degree of correlation between these two variables. The correlation coefficient between credit flow to agriculture and agricultural production is calculated to be 0.94 approximately. This implies that there is a very high positive correlation between these two variables. This can easily be explained by the fact that better credit flow helps agriculture to become more technologically advanced and hence, leads to better production figures. We can also look at it from the other side i.e more agricultural production will lead to development of the sector and thus attract more credit flow. 
One drawback of this correlation analysis is that it is not able to tell us which is the dependent variable and which is the independent one. This limits us from taking our analysis any further. But it does manage to tell us that both the variables move in the same direction with time.

\section{A Simple General Equilibrium Model}

We construct a three-sector general equilibrium model of a small open economy to analyze the implications of a rise in the supply of formal credit. The following are the sectors under consideration:

Sector X is a traditional agricultural sector producing final good which is consumed domestically. This sector does not have any access to the formal capital market and thus it uses only informal credit. Sector $Y$ is an urban manufacturing sector which is import competing. It uses formal capital as the only form of capital. Sector $\mathrm{Z}$ is a modern agricultural sector producing a highly processed agricultural good which is exportable. This sector uses both formal and informal credit. Labour is used in all the three sectors.

We assume that markets are perfectly competitive. Labour moves freely across different sectors. Wage of labour in Sector $\mathrm{Y}$ is unionised and hence the workers receive a high fixed wage, while their counterparts in the other two sectors earn a flexible wage which is less than the fixed wage in sector Y. Workers first try to get employment in the manufacturing sector as it offers a high wage. Those who are not successful in getting jobs in the manufacturing sector are automatically absorbed in the other two sectors owing to complete flexibility of the non-manufacturing wage. Thus full employment prevails in the economy. The supply of informal credit is taken as a function of the relative differential between the interest rates in the informal and formal markets. The supply of formal credit is exogenously given. We assume that formal credit and informal credit are substitutable in nature. Production functions in all the three sectors exhibit constant returns to scale with positive and diminishing marginal productivity to each factor. Owing to our small open economy assumption, prices of both the commodities $\mathrm{Y}$ and $\mathrm{Z}$ are internationally given. However, as sector X produces a non-traded good, its price is determined domestically. We assume a part of labour income is spent on the non-traded traditional agricultural good, $\mathrm{X}$.

We assume that the modern agricultural sector is formal capital intensive relative to the urban manufacturing sector, i.e.:

$$
\frac{a_{k z}}{a_{l z}}>\frac{a_{k y}}{a_{l y}}
$$

Also, we assume that the traditional agricultural sector is labour intensive relative to the modern agricultural sector, i.e.:

$\frac{a_{l x}}{a_{k_{1} x}}>\frac{a_{l z}}{a_{k_{1} z}}$ 


\subsection{Notations}

$a_{l x}$ : Coefficient of labour in sector $\mathrm{X}$ i.e. labour per unit of $\mathrm{X}$;

$a_{l y}$ : Coefficient of labour in sector $\mathrm{Y}$ i.e. labour per unit of $\mathrm{Y}$;

$a_{l z}$ : Coefficient of labour in sector $\mathrm{Z}$ i.e. labour per unit of $\mathrm{Z}$;

$a_{k_{1} x}$ : Informal capital output ratio in the sector $\mathrm{X}$;

$a_{k y}$ : Formal capital output ratio in sector Y;

$a_{k_{1} z}:$ Informal capital output ratio in sector Z;

$a_{k z}$ : Formal capital output ratio in sector Z;

$\alpha$ : Fraction of income spent on output produced by traditional agricultural sector;

$P_{x}:$ Price of non-traded commodity $\mathrm{X}$;

$P_{y}^{*}$ : International price of commodity $\mathrm{Y}$;

$P_{z}^{*}$ : International price of commodity $\mathrm{Z}$;

$w^{*}$ : Wage of labour in sector Y (fixed);

$w$ : Flexible wage of labour in sectors $\mathrm{X}$ and $\mathrm{Z}$;

$R$ : Rate of return on informal credit;

$r$ : Rate of return on formal credit;

$\bar{L}$ : Total supply of labour;

$\overline{K_{1}}$ : Total supply of informal credit;

$K_{f}$ : Total supply of formal credit;

\subsection{Equation Structure}

Given the assumption of competitive markets, the price unit cost equality conditions relating to the three sectors of the economy are given by the following equations. For sake of simplicity, we assume that the factor coefficients are fixed.

\section{Price System}

$$
\begin{aligned}
& P_{x}=w a_{l x}+R a_{k_{1} x} \\
& P_{y}^{*}=w^{*} a_{l y}+r a_{k y} \\
& P_{z}^{*}=w a_{l z}+R a_{k_{1} z}
\end{aligned}
$$

The additional demand for credit in sector $\mathrm{Z}$ is met by informal credit at the market clearing interest rate. Hence, interest rate on informal credit figures in the marginal cost of production.

Given our assumption of full employment, we have the following system of equations. 


\section{Quantity System}

$$
\begin{aligned}
& \bar{L}=a_{l x} X+a_{l y} Y+a_{l z} Z \ldots \ldots \ldots \ldots \ldots \ldots \ldots \ldots \ldots(4) \\
& K_{1}(R-r)=a_{k_{1} x} X+a_{k_{1} z} Z \ldots \ldots \ldots \ldots \ldots \ldots \ldots \ldots(5) \\
& K_{f}=a_{k y} Y+a_{k z} Z \ldots \ldots \ldots \ldots \ldots \ldots \ldots \ldots \ldots \ldots \ldots . . .
\end{aligned}
$$

$\mathrm{X}, \mathrm{Y}$ and $\mathrm{Z}$ denote the output of the respective sectors.

Since a fraction of income, $\alpha$ is spent on output produced by urban informal sector, we have

$$
\alpha\left(w a_{l x} X+w^{*} a_{l y} Y+w a_{l z} Z\right)=X P_{x}
$$

Since there is market clearing, the left hand side of the above equation represents the value of demand and the right hand side of equation represents the value of production. We can write the above equation as:

$$
\alpha\left\{\left(\frac{w}{P_{x}}\right) a_{l x} X+\left(\frac{w^{*}}{P_{x}}\right) a_{l y} Y+\left(\frac{w}{P_{x}}\right) a_{l z} Z\right\}=X
$$

\subsection{Working of the Model}

The endogenous variables of the model are $w, P_{x}, r, R, X, Y, Z$. Thus we have seven endogenous variables and seven independent equations, namely equations (1) - (7). We can solve for the endogenous variables as follows: from equation (2) we get the value of $r$. Then, solving the remaining equations, i.e. equations (1) and (3) - (7) simultaneously, we get $w, P_{x}, R, X, Y$ and $Z$.

\subsection{Comparative Statics}

\section{Effect of Increase in the Supply of Formal Credit}

We consider an increase in the supply of formal credit as indicated by an increase in $K_{f}$. In this three-sector general equilibrium model we will show that this entails a rise in the flexible wage rate and contraction of the traditional agricultural sector alongside an expansion of the modern agricultural sector. The economic interpretation is as follows:

As the endowment of formal capital rises, the sector using formal capital intensively must expand by the Rybczynski Theorem. Given our assumptions regarding the factor intensity relations it follows that the output of the relatively formal capital intensive modern agricultural sector $\mathrm{Z}$ will rise. As $\mathrm{Z}$ rises, from equation (4) either $\mathrm{X}$ or $\mathrm{Y}$ must contract. Let us suppose that sector $\mathrm{X}$ contracts. From equation (7)[or (7.1)], $P_{x}$ will rise. From the Stolper-Samuelson theorem, we know that the wage rate, $w$ will rise too and that the percentage increase in $w$ will be higher than the percentage increase in $P_{x}$. As a result, the real wage measured in the units of the traditional agricultural good rises and the workers are better off. Thus, from equation (3), R must fall. It is clear from equation (2) that there will be no change in the value of $r$. Thus $(R-r)$ falls, and hence, $K_{l}$ falls. Given an increase in Z, it follows from equation (5) that the fall in $\mathrm{X}$ is substantial. 
Proposition: Increased supply of formal credit will lead to expansion of the modern agricultural sector and contraction of the traditional agricultural sector. Wage gap between the urban manufacturing sector and the agricultural sectors decline.

\section{Policy Recommendations}

Given our domain of discussion, we see that agricultural development is the fulcrum of economic growth and well-being of the working class. Hence, the policy implications of the above exercise will revolve around providing the necessary impetus to the flagging agricultural sector of India. Certain policy recommendations may be stated as follows:

1) An increase in the rate of public investment in agriculture not only causes steady growth of agriculture but also influences the overall performance of the economy.

2) A massive financial inclusion drive would improve the well-being of the workers besides augmenting economic growth.

3) The commercial banks should be made open to rural branches. Expansion of microfinance institutions and other non-banking financial corporations will go a long way in formalizing the informal credit in rural India.

4) Rural infrastructure should be strengthened as it often stands in complementary relation with rural credit demanded and access to credit.

5) Along with the formal sources of credit, strengthening of the semi-formal sources of credit known as micro-finance, that follows the market logic within the broad framework of the banking system, is also suggested.

6) Entry of foreign direct investment into microfinance institutions signals a reduction in poverty.

Apart from these, policymakers should focus on three specific dimensions of greater financial inclusion, namely, access (as measured by the size of participation costs), depth (as measured by the size of collateral constraints resulting from limited commitment), and intermediation efficiency (as measured by the size of the interest rate spread, rejecting default probability and asymmetric information).

The Government has a central role to play in enhancing financial inclusion by introducing laws that promote the well-being of the deprived class. Some of the initiatives which are undertaken in this context are:

- Aadhaar- Unique Identification Authority of India (UIDAI).

- Pradhan Mantri Jan-Dhan Yojana (PMJDY).

- Swarnjayanti Gram Swarozgar Yojana (SGSY).

- Kisan Credit Cards (KCC).

- General Purpose Credit Cards (GCC).

- No- Frills Account (NFAs).

\section{Concluding Remarks}

A massive number of unemployed and disguisedly employed individuals found in the rural areas rely on agriculture as their ultimate source of livelihood. Thus it is through agriculture that the economic and social disparity among the different rungs of the society can be erased and the poor 
can aspire for a relatively better standard of living. Our study shows that financial inclusion and social sector spending in the context of agriculture has several favourable impacts on the economy of a country. In a developing country like India, characterized by agricultural over-dependence and severe inequality, financial inclusion has the potential to provide a much-needed impetus to economic development and inclusive growth. Over the years, India has experienced a significant increase in the flow of direct credit to agriculture with a simultaneous decrease in informal lending. However, the declining share of agricultural GDP in the total GDP of the country posits an issue of concern before the society. Also, the benefits of the financial institutions and social credit transfers are usually reaped by a handful of large agricultural farms whereas the small farmers who form the poorer section of the society are excluded. What is necessary in order to overcome these problems is a concrete plan of action and its proper implementation such that financial inclusion can indeed pave the way for major agricultural development in the country and bring about inclusive growth, thus reducing and eventually eliminating the poverty and inequality conditions that prevail in the country. On a concluding note, we look forward to a day when every Indian will have a bank account, and everybody will be a direct participant in the economy.

\section{Acknowledgement}

The author would like to thank Dr. Ranjanendra Narayan Nag, Professor of St. Xavier's College, Kolkata for supervising the paper and Dr. Gautam gupta, Professor of Jadavpur University for providing enormous support and encouragement in writing the paper.

\section{References}

[1] Chaudhuri, S. (2001): 'Interaction of Formal and Informal Credit Markets in Backward Agriculture: A Theoretical Analysis', Indian Economic Review, 36(2), 411-428.

[2] Das, A., Senapati, M. and John, J. (2009): 'Impact of Agricultural Credit on Agriculture Production: An Empirical Analysis in India', Reserve Bank of India Occasional Papers, Vol. 30, No.2, Monsoon 2009.

[3] Gupta, M. R. and Chaudhuri, S. (1997): 'Formal Credit, Corruption and the Informal Credit Market in Agriculture: A Theoretical Analysis', Economica, 64, 331-43.

[4] Marjit, S. and Kar, S. (2007): 'Labour Productivity Growth, Informal Wage and Capital Mobility: A General Equilibrium Analysis', International Policy Centre, University of Michigan, Working Paper \# 54, 2007.

[5] Ramos, Raquel Almeida and Ranieri, Rafael (2013): 'Operationally Defining Inclusive Growth: One Challenge, Two Approaches', The International Policy Centre for Inclusive Growth, One Pager No. 206.

[6] Reserve Bank of India (2004): 'Report of the Advisory Committee on Flow of Credit to Agriculture and Related Activities from the Banking System'.

[7] Tripathi, A. and Prasad, A.R. (2009): 'Agricultural Development in India since Independence', Journal of Emerging Knowledge on Emerging Markets, Volume 1, Issue 1, November 2009.

*Corresponding author.

E-mail address: semanti8@ gmail.com 